\title{
EVALUASI TINGKAT KEBERHASILAN TEKNOLOGI INSEMINASI BUATAN DI DESA SAWOJAJAR
}

\author{
EVALUATION OF THE SUCCESS LEVEL OF ARTIFICIAL INSEMINATION \\ TECHNOLOGY IN SAWOJAJAR VILLAGE
}

\author{
Jonathan Anugrah Lase ${ }^{1}$, Dian Lestari ${ }^{2}$, dan Ulvi Fitri Handayani ${ }^{2)}$ \\ ${ }^{1)}$ Balai Pengkajian Teknologi Pertanian (BPTP) Maluku Utara \\ ${ }^{2)}$ Dosen Program Studi Nutrisi dan Teknologi Pakan Ternak, Universitas \\ Muhammadiyah Kotabumi \\ Email : dian.lestari@umko.ac.id
}

\begin{abstract}
Artificial insemination (AI) is one of the reproductive technologies for increasing the population of beef cattle by increasing the genetic quality of livestock, in a short time it can produce large numbers of good quality calves by utilizing superior bulls. AI technology has become a trend and an option for cattle farmers. However, most farmer do not know how to evaluate the success rate level. Based on the IA trend, an evaluation of the success rate of AI technology in beef cattle was carried out in Sawojajar Village, Kotabumi District. The research method used was the descriptive research method and data collection was carried out according to the purposive sampling method by filling out questionnaires to breeders and inseminators. The variables observed were the results of the perception of the adoption of AI technology, data on the number of livestock in three livestock groups, the number of acceptors, the value of $S / C$, and the level of pregnancy. The results obtained from this study are the adoption of AI technology in beef cattle in the village of Sawojajar which shows the number of Services per Conception (S/C) 3,4 and Conception Rate (CR) of 3,7\% is considered low and needs to be increased. Four factors are thought to cause the low success rate of AI technology, namely bull semen, cows livestock fertility, inseminator skills, and farmer knowledge in identifying estrous phases in livestock.
\end{abstract}

Keywords: Artificial Insemination, Beef Cattle, Conception Rate, Sawojajar, Service per Conception

\begin{abstract}
Abstrak : Inseminasi Buatan menjadi salah satu teknologi reproduksi untuk peningkatan populasi sapi pedaging dengan cara meningkatkan perbaikan mutu genetik ternak, sehingga dalam waktu pendek dapat menghasilkan anak dengan kualitas baik dalam jumlah yang besar dengan memanfaatkan pejantan unggul. Teknologi IB mulai menjadi trend ditingkat peternak sapi pedaging. Namun evaluasi tingkat keberhasilannya belum banyak diketahui. Berdasarkan trend teknologi IB tersebut maka dilakukan evaluasi tingkat keberhasilan teknologi inseminasi buatan pada sapi pedaging di Desa Sawojajar, Kecamatan Kotabumi. Metode penelitian dilakukan adalah metode penelitian deskriptif dan pengumpulan data dilakukan menurut metode purposive sampling dengan cara pengisian kuisioner kepada peternak dan
\end{abstract}


inseminator. Variabel yang diamati yakni hasil persepsi hasil adopsi teknologi IB, data jumlah ternak di tiga kelompok ternak, jumlah ternak aseptor, nilai S/C, dan tingkat kebuntingan. Hasil yang diperoleh dari penelitian ini yakni Adopsi teknologi IB pada ternak sapi pedaging di Desa Sawojajar menunjukkan angka Service per Conception (S/C) 3,4 dan Conception Rate (CR) 3,7\% yang dinilai masih rendah dan perlu ditingkatkan. Ada empat aspek yang diduga menyebabkan rendahnya tingkat keberhasilan teknologi IB yakni semen pejantan, kesuburan ternak betina, keterampilan inseminator, dan pengetahuan peternak dalam mengidentifikasi fase estrus pada ternak.

Kata kunci : Conception Rate, Inseminasi Buatan, Sapi Pedaging, Sawojajar, Service per Conception

\section{PENDAHULUAN}

Indonesia adalah salah satu negara dengan jumlah penduduk yang tinggi. Menurut data BPS 2018 jumlah penduduk Indonesia sebesar 261 juta jiwa dengan laju pertumbuhan penduduk sebesar $1,34 \%$ per tahun. Laju pertumbuhan tersebut diimbangi dengan kebutuhan meningkatnya kebutuhan pangan nabati dan hewani (Lase \& Lestari, 2020). Di Indonesia, sumber pangan hewani asal sapi terutama daging cenderung meningkat setiap tahunnya. Menurut data BPS 2018 pada tahun 2016 produksi daging sapi di Indonesia sebesar 518.484 ton. Desa Sawojajar, Kabupaten Lampung Utara adalah salah satu Kabupaten yang mulai mengembangkan populasi sapi pedaging. Namun pengembangan populasi sapi pedaging di Desa Sawojajar tergolong rendah karena terkendala oleh rendahnya pengetahuan peternak dalam mengelola efisiensi reproduksi ternaknya. Umumnya perangsangan efisiensi reproduksi menggunakan feed additive berupa antibiotik yang berlebihan dapat memicu residu pada produk akhir yang berdampak pada kesehatan (Lestari dkk., 2020).

Produktivitas ternak yang rendah disebabkan oleh pola mengawinkan ternak sapi yang secara alami, sehingga menyebabkan terjadi penurunan tingkat bunting pada ternak. Upaya yang mulai digerakkan pemerintah yakni meningkatkan produksi daging agar tercapai swasembada daging sapi dan kerbau. Upaya mengembangkan aspek pembibitan melalui program persilangan (genetik) (Lestari, dkk. 2021). Salah satu program yang digerakkan yakni penerapan program inseminasi buatan (IB). Berdasarkan beberapa penelitian terdahulu menyatakan bahwa IB telah terbukti 
memberikan dampak positif pada peningkatan populasi ternak. IB atau sering disebut kawin suntik menjadi salah satu teknologi reproduksi untuk peningkatan populasi sapi pedaging dengan cara meningkatkan perbaikan mutu genetik ternak, sehingga dalam waktu pendek dapat menghasilkan anak dengan kualitas baik dalam jumlah yang besar dengan memanfaatkan pejantan unggul sebanyak-banyaknya (Susilawati, 2013). Fenomena ini mendorong para peternak untuk meningkatkan produk hasil peternakan untuk menunjang permintaan pasar (Tel, dkk., 2021). Trend teknologi IB mulai muncul ditingkat peternak sapi di Desa Sawojajar. Hal ini karena peternak dapat mengembangbiakan ternaknya dengan waktu pengawinan yang relatif singkat. Namun evaluasi tingkat keberhasilannya belum banyak diketahui. Berdasarkan trend teknologi IB tersebut maka dilakukan evaluasi tingkat keberhasilan IB pada sapi pedaging di Desa Sawojajar, Kecamatan Kotabumi.

\section{METODE}

Penelitian dilakukan dengan metode deskriptif. Sampel dan pengumpulan data dilakukan menurut metode purposive sampling yaitu mengobservasi 44 ekor sapi pedaging betina yang diperoleh dari 3 kelompok ternak di Desa Sawojajar. Data diperoleh dengan cara observasi dan pendataan kuisioner pada peternak dan inseminator. Pengisian kuisioner dilakukan dengan cara wawancara secara langsung. Data yang yang diamati semua parameter reproduksi yang mengacu pada efisiensi reproduksi dari pelaksanaan IB. Adapun parameter yang diamati yakni persepsi peternak terhadap teknologi IB, Conception Rate, dan Service per Conception (S/C).

\section{HASIL DAN PEMBAHASAN}

\section{A. Persepsi Peternak Sapi Potong Terhadap Inovasi IB}

Persepsi merupakan proses menerima informasi atau stimuli dari lingkungan dan mengubahnya ke dalam kesadaran psikologis yang dapat tergambar dalam bentuk tindakan dari respon stimulus tersebut. Berdasarkan hal tersebut, persepsi setiap individu dapat berbeda-beda pada kondisi yang sama. Hal ini memunculkan adanya variasi kognitif setiap responden. Setiap individu bekerja menurut caranya sendiri tergantung pada aspek-aspek personal peternak, seperti penerimaan terhadap ambiguitas, tingkat keterbukaan atau ketertutupan pikiran, 
dan sebagainya. Pada observasi ini, persepsi peternak sapi potong terhadap inovasi IB diukur dalam bentuk respon responden terhadap aspek teknis pemeliharaan sapi potong. Hasil penilaian pengamatan aspek teknis memberikan gambaran total nilai responden sebesar 441 sedangkan total nilai harapan adalah 885 sehingga baru sebesar $50 \%$ aspek penentu pengembangan sapi potong yang ideal diterapkan oleh peternak responden di Desa Sawojajar (Tabel 1).

Pada Tabel 1 menunjukkan bahwa penerapan aspek teknis dari yang tertinggi hingga terendah berturut-turut adalah perspektif kesehatan hewan (68\%), perspektif pakan (53\%), perspektif kandang dan peralatan (50\%), perspektif tatalaksana $(49 \%)$, dan perspektif pemuliaan (28\%). Selanjutnya, hasil pengujian data sampel menunjukkan adanya variasi pengetahuan yang nyata terhadap aspek pemuliaan dan kesehatan sapi potong antar ke tiga kelompok ternak. Variasi pengetahuan dan keterampilan responden antar lokasi dalam aspek pemuliaan meliputi penggunaan sistem perkawinan sapi potong, jumlah kelahiran per tahun, dan jarak beranak sapi potong per tahun.

Tabel 1. Hasil penilaian tingkat penerapan responden dalam standar aspek teknis budidaya sapi potong

\begin{tabular}{|c|c|c|c|c|c|c|c|c|c|}
\hline \multirow{3}{*}{ Aspek } & \multirow{3}{*}{$\begin{array}{c}\text { Nilai } \\
\text { Harapan }\end{array}$} & \multicolumn{6}{|c|}{ Nilai Pengamatan pada Kelompok } & \multicolumn{2}{|c|}{ Rataan } \\
\hline & & \multicolumn{2}{|c|}{1} & \multicolumn{2}{|c|}{2} & \multicolumn{2}{|c|}{3} & \multirow[b]{2}{*}{ Nilai } & \multirow[b]{2}{*}{$\%$} \\
\hline & & Nilai & $\%$ & Nilai & $\%$ & Nilai & $\%$ & & \\
\hline Pemuliaan & 250 & 40 & 16 & 87 & 35 & 80 & 32 & 96 & 28 \\
\hline Pakan & 300 & 125 & 42 & 150 & 50 & 205 & 68 & 160 & 53 \\
\hline Tata laksana & 175 & 64 & 37 & 90 & 51 & 100 & 57 & 85 & 49 \\
\hline Kesehatan & 110 & 64 & 58 & 94 & 85 & 66 & 60 & 75 & 68 \\
\hline $\begin{array}{r}\text { Kandang dan } \\
\text { peralatan }\end{array}$ & 50 & 10 & 20 & 33 & 66 & 33 & 66 & 25 & 50 \\
\hline Jumlah & 885 & 303 & 34 & 454 & 51 & 484 & 55 & 441 & 50 \\
\hline
\end{tabular}

Penggunaan sistem perkawinan sapi potong di Desa Sawojajar didominasi dengan sistem kawin alam. Adanya sistem perkawinan sapi potong mempengaruhi pengetahuan responden terhadap umur sapi dan tanda sapi birahi. Dalam hal ini, diperlukan pembentukan dan penguatan peran kelompok peternak sebagai media 
komunikasi dalam diseminasi inovasi IB.

\section{B. Dinamika populasi ternak sapi potong di Desa Sawojajar}

Jumlah ternak sapi potong di Desa Sawojajar semakin meningkat seiring dengan kebutuhan daging. Namun jumlah ternak sapi pedaging di Desa Sawojajar tergolong rendah. Hal ini diduga dipengaruhi oleh banyak aspek yakni produktivitas ternak rendah, angka mortalitas tinggi, angka kelahiran rendah, dan keberhasilan IB belum optimal. Umumnya efisiensi pengeluaran ternak lebih banyak dari pada jumlah ternak yang dibudidayakan.

Masyarakat di Desa Sawojajar memanfaatkan komuditi sapi dalam melaksanakan acara adat, agama, dan sosial. Peternakan sapi pedaging di Desa Sawojajar masih dikelola dengan metode pemeliharaan tradisional. Namun saat ini masyarakat beberapa anggota kelompok ternak mulai mengadopsi teknologi sebagai upaya untuk meningkatkan jumlah populasi sapi pedaging yang berkualitas. Salah satu upaya peningkatan yang diadopsi yakni, metode Inseminasi Buatan (IB). Jumlah ternak sapi pedaging di tiga kelompok ternak yakni 44 ekor dengan jantan 28 ekor dan betina 16 ekor (Gambar 1). jumlah betina tergolong rendah dan ditambah dengan kurangnya penerapan teknologi sehingga produksi semakin menurun. Aspek lain yang diduga mempengaruhi lambatnya pertumbuhan populasi karena sapi-sapi betina juga ikut diperjual-belikan dan dipotong sehingga menjadi penghambat pertambahan jumlah populasi. Berdasarkan Gambar 2, jumlah betina aseptor 13 ekor dan 3 ekor sapi betina muda. Ternak sapi betina aseptor dikandangkan bersamaan dengan jantan sehingga memungkinkan untuk perkawinan alami.

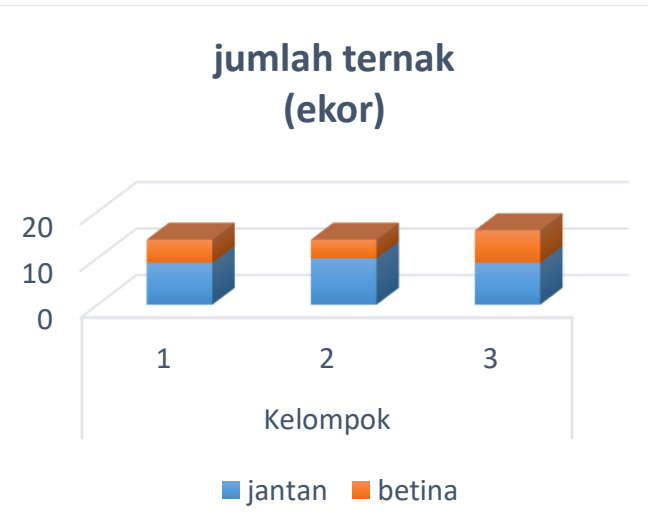

Gambar 1. Jumlah ternak di Desa Sawojajar Tahun 2018-2019 
C. Service per Conception (S/C) pada Ternak Sapi Betina di Desa Sawojajar

Penilaian keberhasilan program IB dari proses reproduksi dinyatakan dengan S/C (Toelihere, 1993). Angka pencapaian jumlah kawin per kebuntingan di 3 kelompok ternak Desa Sawojajar disajikan dalam Gambar 3. Catatan perkawinan di tiga kelompok memperlihatkan bahwa untuk menghasilkan suatu kebuntingan diperlukan 2-4 kali perkawinan atau rata-rata 3,4 kali per kebuntingan. Menurut Hardjopranjoto (1995), persentase jumlah induk yang membutuhkan lebih dari 3 kali perkawinan menunjukkan adanya gangguan reproduksi. Ball \& Peters
(2004), menyatakan bahwa rataan angka pencapaian jumlah kawin perkebuntingan yang dianggap normal adalah 1,6-2,0 kali. Menurut Hafez (2000), sebaiknya sapi dikawinkan paling sedikit $60-80$ hari setelah kelahiran, karena untuk mencapai involusi uteri yang sempurna. Pada penelitian ini angka $\mathrm{S} / \mathrm{C}$ di 3 kelompok ternak mencapai angka 3,4 dan lebih tinggi dibandingkan dengan Ball \& Peters (2004). Hal ini karena aspek kondisi reproduksi pejantan dan betina, keterampilan inseminator, dan pengetahuan peternak dalam mengidentifikasi fase estrus pada ternak.

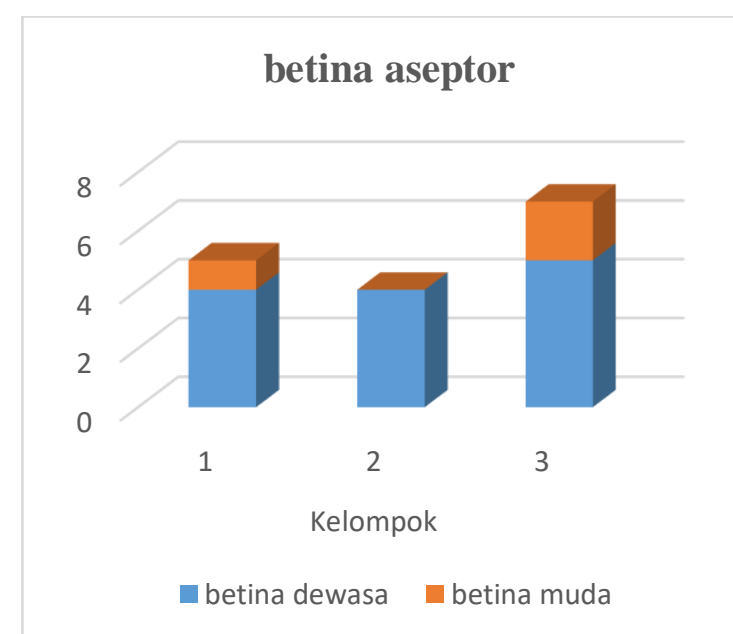

(a)

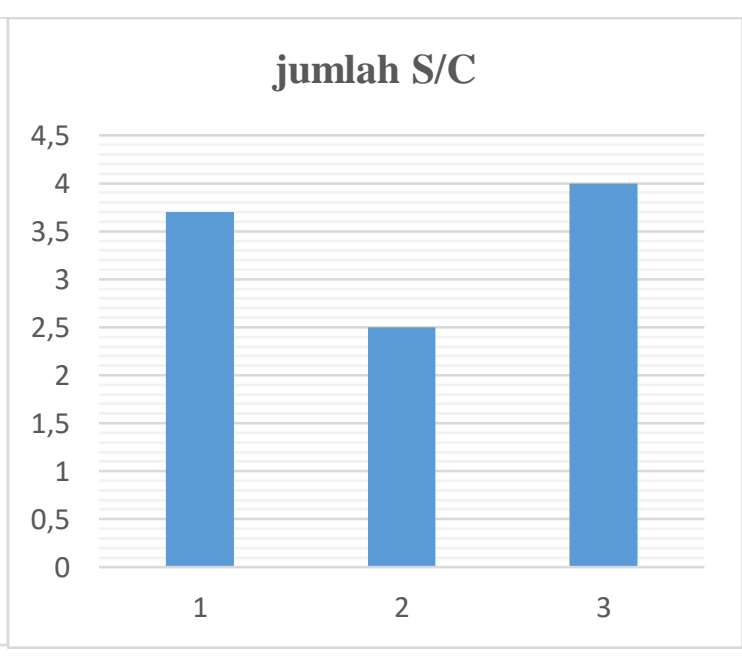

(b)

Gambar 2. (a) Jumlah Betina Aseptor di Desa Sawojajar Tahun 2018-2019 ; (b) Jumlah S/C Ternak Sapi Betina di Desa Sawojajar Tahun 2018-2019 


\section{Conception Rate (CR) pada Ternak} Sapi Betina Dewasa

Angka kebuntingan atau nilai $\mathrm{CR}$ ternak sapi yang dicapai di tiga kelompok ternak yang mengadopsi teknologi IB rata-rata sebesar 3,7\%. Nilai CR pada penelitian ini jauh lebih rendah, dibawah target yang diharapkan oleh Ditjennak tahun 1991 sebesar 62\%
(Widodo, 2000). Hal ini diduga karena rendahnya pengetahuan peternak dalam mengidentifikasi fase estrus ternak, sehingga IB dilakukan terlalu dini atau terlambat. Upaya penerapan IB yang terlalu dini atau terlambat dapat meningkatkan persentase kegagalan IB.

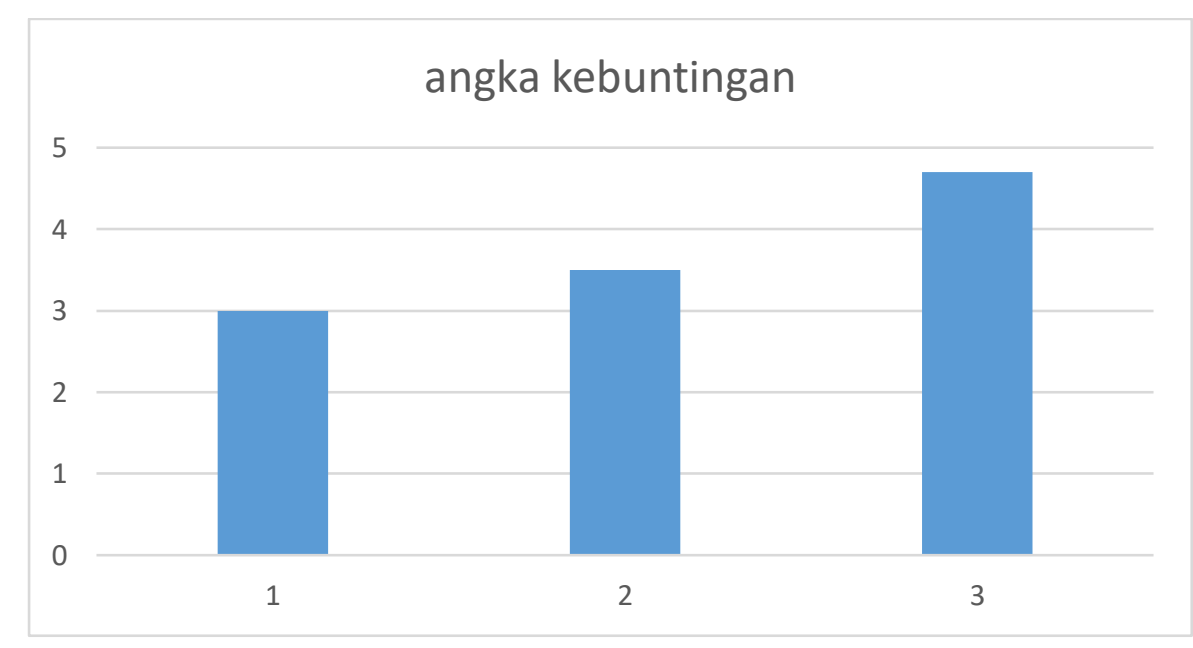

Kelompok

Gambar 4. Angka Kebuntingan Ternak Sapi Betina di Desa Sawojajar Tahun 20182019

IV. PENUTUP

\section{a. Simpulan}

Adopsi teknologi IB pada ternak sapi pedaging di Desa Sawojajar menunjukkan angka S/C sebesar 3,4 dan CR sebesar 3,7\%. Ada empat aspek yang diduga menyebabkan rendahnya tingkat keberhasilan teknologi IB yakni kondisi reproduksi pejantan dan betina,

$$
\begin{array}{llr}
\text { keterampilan } & \text { inseminator, dan } \\
\text { pengetahuan } & \text { peternak } & \text { dalam } \\
\text { mengidentifikasi } & \text { fase estrus pada } \\
\text { ternak. } & &
\end{array}
$$

\section{b. Saran}

Sebaiknya perlu dilakukan kajian lebih lanjut terhadap aspek-aspek yang diduga menyebabkan rendahnya tingkat keberhasilan teknologi IB. 
DAFTAR PUSTAKA

Ball, P. J. H., \& Peters, A. R. (2004). Reproduction In Cattle Third Edition. Blackwell Publishing. Victoria. Australia.

Hafez, E. S. E. 2000. Reproduction in Farm Animal. South Caroline : Lippincoot Williams and Walkins.

Hardjopranjoto. (1995). Ilmu Kemajiran

Ternak. Surabaya : Universitas Airlangga Press.

Lase, J. A., \& Lestari, D. (2020). "Potensi Ternak Entok (Cairina Moschata) Sebagai Sumber Daging Alternatif Dalam Mendukung Ketahanan Pangan Nasional". Seminar Nasional Dies Natalis ke 44 UNS. Universitas Sebelas Maret (UNS) Surakarta. Vol 4 (1): 318-329.

Lestari, D., Rukmiasih, Suryati, T., Hardjosworo, P. S., \& Lase, J. A. (2020). “Komposisi Asam Lemak dan Kadar Malondialdehida Daging Itik Lokal yang diberi Antioksidan Alami”. JIPTHP. Vol. 8(3): 117-123.

Lestari, D., Harini, N. V. A., \& Lase, J.A. (2021). "Strategi dan Prospek Pengembangan Agribisnis Ayam Lokal Indonesia”. Jurnal
Peternakan. E-ISSN: 2599-1736.

Vol. 5 (01): 32-39.

Susilawati, T. (2013). Pedoman Inseminasi Buatan Pada Ternak. Malang: Penerbit Universitas Barwijaya Press.

Tel, B. J., Lestari, D., Endayani, A. S., Lase, J. A., \& Ardiarini, N. (2021). "Efek Curcuma Dan Allium Sativum Terhadap Kadar Lemak Abdomen Dan Kolesterol Darah Ayam Ras Pedaging”. J. Agricultue and Animal Science. Vol.1(1). Hal : 11-18.

Toelihere, M. R. (1993). Inseminasi Buatan pada Ternak. Bandung : Penerbit Angkasa.

Widodo, P. (2000). Pengkajian Pelaksanaan Program Inseminasi Buatan Pada Sapi Potong Di Kabupaten Daerah Tingkat II Blora, Jawa Tengah. Skripsi. Bogor: Fakultas Peternakan Institut Pertanian Bogor. 